\title{
Gantung Diri Sebagai Penyimpangan Sosial Terhadap Norma Agama
}

\author{
Nugrawati ${ }^{1}$, Nursalam ${ }^{2}$ \\ ${ }^{1}$ Pendidikan Sosiologi, Universitas Muhammadiyah Makassar \\ Email: nugrawati@gmail.com \\ ${ }^{2}$ Pendidikan Sosiologi, Universitas Muhammadiyah Makassar \\ Email: nursalam@unismuh.ac.id
}

\begin{abstract}
This study aims to find out what is behind the exploitation of child labor and what are the steps of the government to minimize the exploitation of child labor in the city of Makassar, especially in the Manggala subdistrict. The type of research used is descriptive qualitative research method by means of sampling through Purposive Sampling techniques by selecting a number of informants who have criteria that have been determined by researchers who know about the exploitation of child labor. The results of the study show that the background of the causes of exploitation of child labor in the city of Makassar is the factors of poverty and the influence of the social environment around it. and as for the steps taken by the government to minimize exploitation of child labor by opening free education around the area and by providing understanding to parents that the child should have an education not work.
\end{abstract}

Keywords: Exploitation, Child Labor and Social Aberration

Abstrak: Penelitian ini mengkaji tentang Penyimpangan Sosial Terhadap Norma Agama (Studi Kasus Gantung Diri Siswa SMA Negeri 1 Lappariaja). Masalah dalam penelitian ini adalah faktor yang melatarbelakangi terjadinya kasus gantung diri dan dampak yang di timbulkan dari kasus tersebut. Tujuan penelitian ini adalah (i) Mengungkapkan penyebab bunuh diri siswa Sma Negeri 1 Lappariaja kabupaten Bone, (ii) Mengetaui dampak yang ditimbulkan dari kasus bunuh diri tersebut, (iii) Menemukan solusi pengendalian atau pencegahan bunuh diri dalam rangka menciptakan ketentraman masyarakat. Penelitian ini menggunakan pendekatan deskriptif kualitatif dan teknik Purposive Sampling. Teknik penelitian Observasi, wawancara dan dokumentasi. Hasil penelitian ini memberikan gambaran tentang (i) Penyimpangan sosial terhadap norma agama dalam kasus gantung diri dipersepsikan sebagai salah satu bentuk depresi dari pemikiran yang masih labil, (ii)adapun faktor yang melatarbelakangi terjadinya kasus gantung diri adalah faktor ekonomi keluarga yang terlilit utang sehingga anak menjadi sasaran kemarahan dan kekesalan penagih utang, (iii) Cara pengendalian yang dapat ditempuh, yaitu pendekatan keluarga, Lembaga pendidikan atau sekolah, masyarakat.

Kata Kunci : Penyimpangan Sosial, Norma dan Agama.

\section{PENDAHULUAN}

Penyimpangan merupakan sisi negatif dari bentuk perilaku positif, perilaku yang tidak sesuai dengan norma-norma yang ada di dalam masyarakat, baik itu norma hukum, norma kesusilaan, kesopanan dan juga norma agama. Menurut Bruce J, Cohen, ukuran yang manjadi dasarnya penyimpangan bukan baik atau buruk, benar atau salah menurut 
pengertian umum, melainkan berdasarkan ukuran norma dan nilai sosial suatu masyarakat. Penyimpangan sosial pada umumnya dikaitkan dengan hal-hal yang negative. Dalam norma agama, tindakan gantung diri ini merupakan suatu penyimpangan sosial. Karena dalam pandangannya norma agama ini merupakan peraturan hidup yang harus diterima manusia sebagai perintah-perintah, larangan-larangan dan ajaran-ajaran yang bersumber dari tuhan yang maha esa. Norma agama di tujukkan bagi umat manusia agar mematuhi segala perintahnya dan menjauhi segala larangannya. Yang bersumber dari kitab suci bagi masingmasing penganut agama. Tetapi pelanggaran terhadap norma agama akan mendapatkan hukuman dari tuhan yang maha Esa berupa " siksa" kelak di akhirat berbeda dengan normanorma lainnya.

\section{LANDASAN TEORI}

Menurut James V. Zanden (Nurseno, 2007:101), penyimpanan merupakan perilaku yang oleh sejumlah besar orang dianggap sebagai hal tercela dan diluar batas toleransi. Nurseno (2007: 102) penyimpangan sebenarnya tidak selalu berarti negatif, melainkan ada yang positif. Dengan demikian, penyimpangan sosial dapat di bedakan menjadi dua macam, yaitu: (i) penyimpangan positif Penyimpangan yang terarah pada nilai-nilai sosial yang ideal (didambakan) walaupun cara yang dilakukan itu seolah-olah menyimpang dari norma yang berlaku, padahal sebenarnya tidak. Seseorang dikatakan menyimpang secara positif jika dia berusaha merealisasikan suatu cita-cita, tetapi masyarakat tidak dapat menerima caranya, (ii) Penyimpangan Negatif Penyimpangan negatif adalah kecenderungan bertindak kearah nilai-nilai sosial yang di pandang rendah dan akibatnyapun selalu buruk. Contohnya, seseorang yang melakukan tindakan pencurian, pelacuran atau perkosaan. Norma agama yakni ketentuan-ketentuan hidup bermasyarakat yang bersumber pada ajaran agama.Norma agama merupakan suatu petunjuk hidup yang datangnya dari Tuhan Yang Maha Esa.Norma agama di tujukkan bagi manusia agar mematuhi segala perintah serta larangannya. Masing-masin penganut agama meyakini bahwa petunjuk yang ada dalam kitab sucinya merupakan hal yang harus diyakini, diikuti, serta ditaati.Kitab suci merupakan petunjuk serta tuntutan hidup kejalan yang baik dan benar karena perintah atau larangan itu datangnya dari tuhan. Menurut Teori Rawlin's ( 1993), bunuh diri adalah peruatan yang dilakukan seseorang dengan sukarela dan disengaja untuk mengakhiri hidupnya. Bunuh diri 
dalam agama islam, sangat diharamkan karena sama halnya mendahului ketentuan mati, dimana hidup dan mati hanya Allah yang mempunyai kekuasaan untuk hal itu. Apabila seseorang mati dengan cara bunuh diri pasti kelak di akhirat mendapat sisksa dan cara matinya pula tidak diridhoi olehnya, sehingga neraka menjadi tempat kembalinya orang yang mati dengan cara bunuh diri. (Muhammad Adam Hussein : 2012). Berikut dalil AlQuran tentang bunuh diri: " Janganlah ka lian membunuh diri kalian, sesungguhnya Allah maha penyayang. Barang siapa berlaku demikian dengan melanggar hak dan aniaya, maka kelak akan memasukkannya ke dalam neraka. Yang demikian itu adalah mudah bagi Allah". (QS. An-Nisa : 29-30).

\section{METODE PENELITIAN}

Jenis penelitian yang dilakukan penelitian kualitatif yang bertujuan memahami Penyimpangan sosial terhadap norma agama dalam kasus gantung diri siswa SMA Negeri 1 Lappariaja yang terdapat di desa Ujung Lamuru Kabupaten Bone. Informan ditentukan secara Purposive Sampling, teknik pengumpulan data yaitu observasi, wawancara dan dokumentasi, kemudian di analisis melalui tahapan pengumpulan data (data collection), reduksi data (data reduction), penyajian data (display data), penarikan kesimpulan (conclusion) dan menggunakan teknik keabsahan data triangulasi metode, sumber, antar peneliti dan teori.

\section{PEMBAHASAN}

Penyimpangan sosial atau biasa disebut perilaku menyimpang merupakan perilaku yang tidak sesuai dengan norma-norma dan nilai-nilai yang dianut masyarakat atau kelompok.Tidak semua orang bertindak berdasarkan norma-norma dan nilai-nilai sosial yang berlaku dalam masyarakat. Oleh karena itu tindakan yang tidak sesuai dengan norma dan nilai sosial tersebut dinamakan perilaku menyimpang. Berkaitan dengan penyimpangan sosial yang terjadi terkait dengan kasus bunuh diri siswa SMA Negeri 1 Lappariaja Kabupaten Bone, dapat dilihat dari hasil penelitian bahwa kasus bunuh diri ini merupakan suatu penyimpangan terhadap norma agama, bagaimanapun bentuk dan alasan bunuh diri tetap saja melanggar dan dilarang. Selain itu, Firman Allah dalam surat An־Nisa ayat 29-30; 
Artinya: dan janganlah kamu membunuh diri mu, sesungguhnya Allah adalah maha penyayang kepada kamu. Dan barang siapa berbuat demikian dengan melanggar dan aniaya, maka kami kelak akan memasukannya kedalam neraka demikian itu adalah mudah bagi Allah.

Bunuh diri biasanya karena menderita jasmaninya seperti memikirkan bagaimana cara melunasi utang-utangnya, banyak masalah atau menderita rohaninya seperti putus cinta atau sering mendapat perlakuan tidak adil, sehingga berfikir tidak ada gunanya untuk hidup dan jalan satu-satunya adalah mengakhiri hidupnya untuk menghilangkan semua beban yang ada dalam dirinya. Intinya, baik menderita Rohani maupun Jasmaninya, samasama tidak mampu menghadapi kenyataan hidup ini yang tidak akan selalu mulus tapi silih berganti rintangan hidup yang ada. Hal ini berkaitan dengan teori Bunuh Diri' yang dikemukakan oleh Emile Durkheim, yang mengatakan bunuh diri tidak terjadi hanya dipicu kondisi mental. Barangkali benar bahwa orang tertentu punya kecanderungan bunuh diri lebih kuat dari pada orang lain, dan variable eksternal yang berpotensi memicu orang bunuh diri. Baik itu berupa tuntutan sosial, perubahan zaman, dll. Faktor yang melatarbelakangi terjadinya kasus bunuh diri pada siswa SMA Negeri 1 Lappariaja Kabupaten Bone, yaitu;(1) Faktor Ekonomi adalah salah satu faktor utama yang melatarbelakangi terjadinya kasus bunuh diri ini. Banyaknya kebutuhan dan tuntutan kehidupan membuat seseorang rela mengambil suatu resiko demi kelangsungan hidup yang akan datang. Seperti halnya yang dilakukan kebanyakan masyarakat misalnya merantau untuk mendapatkan penghasilan yang lebih baik lagi untuk bisa menutupi kebutuhan yang semakin kompleks.

Merantau dan meninggalkan anak dirumah dengan utang, tentu saja akan berdampak negatif bagi anak. Sesuai dengan teori Bunuh diri yang dikemukan oleh Emile Durkheim tentang bunuh diri dalam kesatuan kelurga, disimpulkan bahwa semakin kecil jumlah anggota dari suatu keluarga, maka akan semakin kecil pula keinginan untuk hidup. Kesatuan sosial yang semakin besar, mengikat orang pada kegiatan-kegiatan sosial diantara anggota-anggota kesatuan tersebut. Tentu saja bukan tidak mungkin, jika bunuh diri ini terjadi akibat dari kesendirian itu, sehingga menyiksa batinnya dan berdampak negatif pada fisiknya. Dapat dikaitkan dengan teori sosialisasi. Teori ini muncul karena adanya penyimpangan dalam teori ini, jelas karena seseorang tidak dapat menghayati nilai dan 
norma yang berlaku dlam suatu masyarakat, hal ini terjadi karena adanya kesalahan dari proses sosialisasi, bisa dari keluarga, lingkungan bermain, sekolah ataupun media massa yang akhirnya memunculkan suatu penyimpangan. Jadi dari pendapat beberapa informan melalui wawancara dan angket, faktor yang melatarbelakangi penyimpangan tersebut adalah ekonomi keluarga dan kurangnya proses sosialisasi dari keluarga sehingga menimbulkan penyimpangan terhadap proses sosialisasi dalam keluarga. Faktor lingkungan sosial juga sangat berpengaruh besar dalam pembentukan kepribadian seorang anak, media kedua yang dia temui setelah keluarga adalah lingkungan bermain. Seorang akan menemui hal yang baru, teman baru selain dalam ruang lingkup keluarga.Dalam pergaulan tentu saja ada batas-batas yang harus diperhatiakan agar tidak menyimpang dari norma dan nilai yang berlaku dalam masyarakat. Dalam kasus Bunuh Diri ini, berkaitan dengan teori anomie yang mengtakan bahwa munculnya perilaku menyimpang merupakan konsekuesi dari perkembangan norma masyarakat yang emakin lama semakin kompleks. Hal ini membuat masyarakat bingung memilih norma sosial yang bisa dijadikan panutan. Biasanya pada teori ini berdampak pada anak, yang orang tuanya bekerja dan tidak berada dirumah, sementara anak tinggal sendiri. Jika kita perhatikan tentu saja hal ini sama yang dialami oleh korban bunuh diri, yang memilih mengakhiri hidunya untuk mengurangi beban dalam dirinya, hal ini bisa saja terjadi kerena terlalu banyak norma yang ada dalam masyarakat, sehingga anak tersebut tidak tahu mana yang salah dan mana yang benar karena peran orang tua terhadap dirinya sangat kurang sehingga mengakibatkan hal yang buruk bagi dirinya sendiri.

Tentu saja hal ini sama yang dialami oleh korban bunuh diri, jika kita perhatikan dengan baik. Korban memilih mengakhiri hidunya untuk mengurangi beban dalam dirinya, hal ini bisa saja terjadi kerena terlalu banyak norma yang ada dalam masyarakat, sehingga anak tersebut tidak tahu mana yang salah dan mana yang benar karena peran orang tua terhadap dirinya sangat kurang sehingga mengakibatkan hal yang buruk bagi dirinya sendiri. Pada masa remaja seorang anak, peran orang tua sangat mempengaryhi pola tingkah laku seorang anak dalam masyarakat, dia akan merasa lelah mengahadapi dunia luar dan disinilah peran orang tua, agar dapat membantu anak cara menghadapi dunia luar, membantu meberikan solusi bagi anak dalam menyelesaikan masalah yang dihadapinya. Implementasi negative Bunuh Diri, keluarga yang ditinggalkan akan menaggung beban yang bertambah berat, pasti bunuh diri akan menajdi aib bagi keluarga, dan bagi pelaku bunuh 
diri, sudah dijelaskan dalam surat An-Nisa ayat 29-30, yang mengatakan bahwa " siapa yang melakukan bunuh diri, dan aniaya maka akan dimasukkan dalam neraka dan kekal didalamnya". Dari pemaparan diatas, jelas bahwa yang akan merasakan dampak dari kasus bunuh diri tersebut adalah keluarga yang ditinggalkan dan terutama pelaku bunuh diri yang memang jelas sudah dijanjikan tempat dineraka sebagai tempatya yang kekal.Tidak hanya merasa kehilangan, tetapi keluarga yang ditinggalkan akan merasa malu akibat dari kejadian ini, tentu saja cap/ pelabelan masyarakat terhadap kelurga dalam artian orang tua akan terus teringat dalam benak masyarakat, bahwa penyebab utama Bunuh Diri tersebut adalah utang orang tua yang harus berujung pada hilangnya nyawa anak kandung mareka sendiri. Tentu saja hal ini menjadi pukulan yang sangat keras bagi orang tua yang harus kehilangan anaknya, orang tua pasti merasa bahwa dia yang telah membunuh anaknya, karena kesalahan kecil yang berakibat fatal.

Bunuh diri yang dilakukan karena kurangnya kasih sayang dari kelurga, yang meninggalkannya sendiri dirumah untuk jangka waktu yang cukup lama dengan beban utang yang berdampak pada si anak. Tentu saja faktor utama yang menyebabkan bunuh diri tersebut adalah faktor ekonomi. Bunuh diri merupakan masalah yang kompleks karena tidak diakibatkan oleh penyebab atau alasan tunggal. Tindakan Bunuh diri merupakan interaksi yang kompleks dari faktor biologik, genetik, psikologik, sosial, budaya dan lingkungan. Sulit untuk menjelaskan mengenai penyebab mengapa orang memutuskan untuk melakukan bunuh diri, sedangkan yang lain dalam kondisi yang sama bahkan lebih buruk tetapi tidak melakukannyaMeskipun demikian, tindakan bunuh diri atau percobaan bunuh diri pada umumnya dapat dicegah, (1) Upaya pencegahan yang dapat dilakukan oleh keluarga, Membina hubungan yang erat dengan pelaku, penuh perhatian, mendengarkan, menghargai perasaan serta memahami emosinya, Dengan memberikan perhatian yang penuh kasih sayang, pengertian dan dukungan dapat mencegah tindakan bunuh diri. (2) Upaya pencegahan yang dapat dilakukan oleh masyarakat dan jaringan yang lebih luas, Masyarakat dapat membantu program pencegahan bunuh diri dengan cara mengangkat isu lokal, masalah dan penyebab bunuh diri kepada pengambil keputusan (misalnya memperbaiki kualitas hidup masyarakat ekonomi lemah, mengurangi tindak kekerasan dan kriminalitas, menghilangkan stigma, menghilangkan sikap diskriminasi, mempengaruhi media massa lokal dan memperbaiki informasi data tentang bunuh diri). (3) Upaya 
pencegahan yang dapat dilakukan oleh Guru, Akhir-akhir ini bunuh diri pada anak dan remaja semakin meningkat. Penyebab utama adalah kegagalan di sekolah, masalah tekanan dari orangtua, tuntutan prestasi sekolah terlalu tinggi, putus cinta dan konflik. Adapun yang dapat dilakukan untuk mencegah terjadinya bunuh diri misalnya, Memberikan pendidikan keterampilan hidup yang dikombinasikan dengan pendekatan pemecahan masalah merupakan modal untuk menghadapi dan mengatasi kehidupan dengan cara yang realistik dan optimistic, guru bisa membantu mengubah perilaku siswa ("agents of change") bagi siswa,

Teori pengendalian atau Kontrol bisa membantu dalam mencagah penyimpangan terbut. Dalam teori ini berpendapat bahwa munculnya perilaku menyimpang pada dasarnya dipengaruhi oleh dua faktor yaitu pengendalian dari dalam berupa norma-norma yang diahyati dan pengendalian dari luar, berupa berupa imbalan sosial terhadap konformitas dan sanksi atau hukuman bagi warga masyarakat yang melanggar norma sosial yang berlaku. untuk mencegah perilku menyimpang tersebut, maka teori kontrol memberikan solusi yaitu: meningkatkan rasa kepercayaan terhadap lembaga-lembaga dasar masyarakat seperti sekolah, keluarga dll, dan yang pasti percaya pada norma-norma yang dihayati.

\section{KESIMPULAN}

Berdasarkan dari hasil penelitian yang telah dilakukan, maka dapat disimpulkan bahwa penyimpangan sosial terhadap norma agama (studi kasus gantung diri siswa SMA Negeri 1 Lappariaja) memang benar adanya, kasus bunuh diri yang terjadi termasuk perbuatan yang melanggar. Jika dulu di Negara-negara barat dengan tegas menetapkan hukuman bagi pelaku bunuh diri dan percobaan bunuh diri, maka Alquran dari dulu sampai sekarang dengan tegas melarang bunuh diri kerena hidup mati seseorang ada di tangan Allah, peraturan itu tidak pernah terhapus atau bahkan hilang sampai kapanpun.

Oleh karena itu jelas adanya bahwa perbuatan pembunuh diri sendiri itu, tidak diperbolehkan apapun alasannya. Adapun penyebab bunuh diri, bisa disebabkan karena menderita jasmani atau rohaninya, faktornya bisa saja kerena, kondisi ekonomi yang tidak stabil, kondisi lingkungan sosial yang timpang atau bahkan dan kondisi keluarga yang tidak harmonis. 
Semua itu merupakan hal yang dapat membuat seseorang mungkin akan berfikir untuk bunuh diri. Adapun dampak yang akan ditimbulkkan dari bunuh diri itu beragam. Tetapi yang paling mersakan dampak tersebut adalah keluarga yang ditinggalkan, bukan Cuma kehilangan seseorang yang berharga tetapi beban malu yang akan melekat dipandangan masyarakat terhadap kelurga korban, atau merupakan pelabelan yang diberikan masyarakat dan akan diingat masyarakat mengenai faktor penyebab bunuh diri tersebut. Dalam mencegah bunuh diri pada remaja, tentu saja sarana utama yang sangat berperan penting dalam menangani hal ini adalah keluarga dalam artian kedua orang tua yang merupakan sarana awal seorang anak mengenal dunia yang lebih luas, selain itu pergaulan dalam lingkungan sosial seorang anak juga sangat berpengaruh, dengan siapa anak itu bergaul, akan mempengaruhi pola tingkah lakunya. Dari ulasan diatas, bisa ditarik kesimpulan bahwa memang bunuh diri adalah sesuatu yang tidak dibenarkan, dalam segi, bentuk dan wujud apapun itu. Tidak ada jalan yang mengarahkan bunuh diri akan berdampak positif baik itu bagi diri sendiri, keluarga ataupun masyarakat luas. Bahkan dalam teori yang diungkapkan oleh Emile Durkheim bahwa dalam bunuh diri terdapat tuga macam kesatuan sosial yang pokok dalam masyarakat antara lain; Bunuh diri dalam kesatuan Agama, Bunuh diri dalam kesatuan keluarga, Bunuh diri dalam kesatuan politik, itu tidak dibenarkan dalam alquran. Karena dalam alquran, sangat jelas menegaskan bahwa bunuh diri dengan alasan apapun tidak dibenarkan dan tempat bagi ornag yang melakukan bunuh diri adalah neraka yang kekal, tentu saja hal itu merupakan bentuk teguran yang diberikan karena telah melanggar ketentuan Allah, bahwa hidup mati seseorang ada ditangan Allah.

\section{DAFTAR PUSTAKA}

Agussalim, A. M. (2004). Ilmu Sosial Budaya Dasar.Makassar : UPT. Mata kuliah umum, Universitas Negeri Makassar.

Alam S, Hendry Hidayat. (2006). IImu pengetahuan sosial untuk tingakat SMK kelas XI. Jakarta: Erlangga.

Al-Jalili, Iman Shalahuddin. (2007). Qishas-qishas Orang yang Bunuh Diri. Jombang: Lintas Media. Archive. (2010). Makalah Kecenderungan Bunuh Diri pada Remaja. (Diakses 2 September 2015). Caray. (2001). Makalah dan Skripsi Bunuh Diri (Syariat Islam). (Diakses 2 September 2015).

Gan Islam. Bunuh Diri Dalam Pandangan Islam.( Diakses 16 agustus 2014).

Haryanto Sindung. (2015). Sosiologi Agama: dari Klasik hingga Postmodern. Yogyakarta: Ar-Ruzz Media.

Hidayat Yusuf Muarif. (2013). Belaar Untuk Menjadi Manusia. (Diakses 30 September 2015). 
Johnson, Doyle Paul. (1986). Teori Sosiologi Klasik dan Modern.Jilid 1. Jakarta: PT Gramedia. Lisa. Sosialisasi.(diakses tanggal 20 November 2008).

Muhammad Abduh Tuasikal. (2014). Hukum menyalatkan orang yang mati Bunuh Diri. (Diakses 29 Agustus 2015).

Muhammad Adam Husain (2016). Kajian Bunuh Diri. (diakses tanggal 20 april 2012).

Nova Riyanti Yusuf. (2015). Bunuh diri dan Upaya Pencegahan. (Diakses 2 September 2015).

Nurseno. (2007). Sosiologi untuk Tingkat SMA Kelas X. Solo: PT Tiga Serangkai Pustaka Mandiri. Permata Pilihan.(2005).Gambaran umum Kabupaten Bone. (Diakses 2 september 2015).

Sasianagilar, (2011). Eksistensi Sosiologi dalam Menanggulangi Perilaku Menyimpang yang Dilakukan

Remaja dengan Teori Labeling sebagai Faktor Utamanya. (diakses tanggal 26 Januari 2011).

Senja, Ungu Langit (2014). Sekilas Tentang Teori Labelling.(Diakses 1 Agustus 2014).

Soekanto, Soerjono. (2007). Sosiologi Suatu Pengantar. Jakarta: PT Raja Grafindo.

Sunarto, Kamanto. (2004). Pengantar Sosiologi. Jakarta: Lembaga Penerbit Fakultas Ekonomi

Universitas Indonesia.

Zulkaedah. (2015). Bunuh Diri dan Apa Dampaknya. (Diakses 29 Agustus 2015). 